\title{
Bell Pepper Yield as Influenced by Plant Spacing and Row Arrangement
}

\author{
Salvadore J. Locascio and William M. Stall \\ Horticultural Sciences Department, Institute of Food and Agricultural Sciences, University of Florida, \\ Gainesville, FL 32611
}

Additional index words. Capsicum annuum, plant spacing, plant population, $\mathrm{N}$ rate

\begin{abstract}
Studies were conducted to evaluate the effects of plant spacing, row arrangement, and $\mathrm{N}$ rate on bell pepper (Capsicum annuum L.) fruit production. Peppers were grown on a recently cleared sandy soil on raised polyethylene mulch beds during 2 years with one and two plant rows on 1.22-m beds and two and three plant rows on 1.83-m beds with two in-row plant spacings and two $\mathrm{N}$ rates. Marketable fruit production was similar during the 2 years. Yields per plant were $30 \%$ greater with a 0.31 - than a 0.23 -m in-row plant spacing. Even with the $33.3 \%$ larger number of plants per ha with the latter in-row spacing, yields per ha were similar with both in-row spacings. Yields per plant also varied with bed arrangement and were $50 \%$ greater with one row $/ 1.22-\mathrm{m}$ bed than with two rows $/ 1.22-\mathrm{m}$ bed or three rows $/ 1.83-\mathrm{m}$ bed. Plant populations were double with the two latter arrangements $(53,818$ plants/ha) than the former $(25,909 \mathrm{plant} / \mathrm{ha})$ arrangement with a $0.31-m$ in-row spacing. Thus, total yields were significantly greater with row arrangements with higher than lower plant populations. With three rows $/ 1.83-\mathrm{m}$ bed, the marketable fruit yields per plant were $19 \%$ lower for plants grown on the inside plant row than from plants grown on the outside plant rows. Leaf tissue $\mathrm{N}$ concentrations were higher during the season with 224 than with $135 \mathrm{~kg}$ N/ha, but yield was not influenced by $\mathrm{N}$ rate.
\end{abstract}

Bell pepper is extensively grown in Florida on fumigated raised beds covered with polyethylene mulch and irrigated. During the 1991-92 season, bell pepper production on 8,660 ha had a farm value of \$171 million (Florida Agricultural Statistical Service, 1993) and accounted for $10 \%$ of the farm value of vegetables in Florida. Bell pepper is commonly grown in one plant row/0.8- to 1.2 -m wide bed or two plant rows/1.5- to $1.8-\mathrm{m}$ wide bed with an in-row plant spacing of $\approx 0.25$ to $0.31 \mathrm{~m}$ for a range of 18,000 to 50,000 plants/ha (Hochmuth et al., 1988). In a study with two plants per hill and two plant rows/1.8-m bed, yields increased with a reduction of in-row spacing from 0.51 to $0.25 \mathrm{~m}$ (Stoffella and Bryan, 1988). With pepper grown in two rows/1.8-m bed, Everett and Subramanya (1983) obtained higher yields with a $0.1-\mathrm{m}$ spacing than with $0.2-$ and $0.3-\mathrm{m}$ spacing in two of three seasons. In the third season, yields were higher and similar with the 0.2 - and $0.3-\mathrm{m}$ spacing than with the $0.1-\mathrm{m}$ spacing, respectively. In a study with unmulched pepper grown on 0.9-m beds, Batal and Smittle (1981) reported that yields were similar with two or three plant rows per bed with an in-row spacing of $0.28 \mathrm{~m}$ and with three plant rows with 0.28 - or $0.41-\mathrm{m}$ in-row spacings. Yields were higher with two rows/0.9-m bed with a $0.28-\mathrm{m}(40,000$ plants/ha) than with a $0.41-\mathrm{m}(27,000$ plants/ha) in-row plant spacing.

Plant population and row arrangement influences marketable yields of other crops grown on raised beds including tomato (Bryan et al., 1968, Navarro and Locascio, 1971) and watermelon (Brinen et al. 1979). Maximum plant yields in tomato were related to a plant arrangement that more nearly approaches a square (Sayre, 1959).

Bell pepper response to polyethylene mulch varies from no response in relatively dry years with split applications of $\mathrm{N}$ to substantial response in wet seasons (Locascio et al., 1985). In a review of pepper fertilization, maximum yields on sandy soil were produced with polyethylene mulch with 180 to $200 \mathrm{~kg} \mathrm{~N} / \mathrm{ha}$ (Hochmuth and Hanlon, 1989).

Received for publication 19 Jan. 1994. Accepted for publication 21 Apr. 1994. Florida Agricultural Experiment Station series no. R-03614. The cost of publishing this paper was defrayed in part by the payment of page charges. Under postal regulations, this paper therefore must be hereby marked advertisement solely to indicate this fact.
In a preliminary report of the present study, Locascio and Stall (1982) found that marketable yields were influenced more by the number of plant rows per bed than by in-row spacings of 0.23 and $0.31 \mathrm{~m}$. The study reported here was conducted to determine the effects of plant population as affected by row arrangement, in-row plant spacing, and $\mathrm{N}$ rate on pepper yield.

\section{Materials and Methods}

Bell peppers were grown on adjacent sites of a recently cleared virgin Mulat fine sandy (Typic Ochraquults) soil located near Gainesville, Fla., during Spring 1982 and 1983. Treatments were factorial combinations of four bed arrangements, two within-row plant spacings, and two $\mathrm{N}$ rates. Bed arrangements were a) one plant row on 1.22-m beds center to center with 0.61-m tops, b) two plant rows on 1.22 -m beds, c) two plant rows on 1.83 -m beds center to center with $0.91-\mathrm{m}$ tops, and d) three plant rows on 1.83 -m beds. Multiple plant rows were spaced $0.31 \mathrm{~m}$ apart on the bed. Plant spacings within rows were 0.23 and $0.31 \mathrm{~m}$, and $\mathrm{N}$ rates were 135 and $224 \mathrm{~kg} \cdot \mathrm{ha}^{-1}$. Treatments were arranged in a split-plot design, with row arrangement as main plots and with in-row plant spacing and $\mathrm{N}$ rate as subplots. With an 0.31 -m in-row plant spacing, plant populations with one plant row/1.22-m bed, two rows/1.22-m bed, two rows/1.83-m bed, and three rows/1.83-m bed were 26,875 , $53,750,35,835$, and 53,750 plants/ha, respectively, and with the 0.23 -m in-row plant spacing were $35,744,71,488,47,661$, and 71,488 plants/ha, respectively. Plots were single beds $9.2 \mathrm{~m}$ long and treatments were replicated four times. Soil at the experimental site had a $\mathrm{pH}$ of 5.3 and an organic matter content of $1.7 \%$ in the upper $15 \mathrm{~cm}$. Dolomitic limestone was applied at $1.7 \mathrm{Mg} \cdot \mathrm{ha}^{-1}$ to adjust the soil $\mathrm{pH}$ to 6.0 to 6.5 . The soil was fumigated with 56 liter $\cdot \mathrm{ha}^{-1}$ ethylene dibromide applied broadcast for nematode control 2 weeks before bed preparation. Nitrogen at 135 and $224 \mathrm{~kg} \cdot \mathrm{ha}^{-}$ ${ }^{1}$, two-thirds from ammonium nitrate and one-third isobutylidene diurea (IBDU), and $112 \mathrm{P}-202 \mathrm{~K}\left(\mathrm{~kg} \cdot \mathrm{ha}^{-1}\right)$ from concentrated superphosphate and potassium chloride, respectively, were applied broadcast on the raised bed tops and incorporated 15 to $20 \mathrm{~cm}$ into the beds. Black polyethylene mulch $(0.038 \mathrm{~mm})$ was applied, and 20-cm-tall 'Keystone Resistant Giant' container-grown pep- 
per plants were transplanted on 23 Mar. 1982 and 17 Mar. 1983. Overhead irrigation was applied as needed. Pesticides were applied weekly to control insects and disease (Hochmuth et al., 1988).

Mature leaves were sampled on 13 May, 10 June, and 30 June 1982 and on 12 May, 9 June, and 7 July 1983 and analyzed for N by the micro-Kjeldahl method (Kirk, 1950). Fruit were harvested at five weekly intervals in 1982 beginning on 27 May and in 1983 on 9 June, 20 June, and 7 July. Fruit were graded by U.S. Dept. of Agriculture standards into U.S. no. 1 and U.S. no. 2 fruit. Data for the 2 years were analyzed by analysis of variance and means were separated by Duncan's multiple range test. Harvests 1 and 2 in 1982 and harvest 1 in 1983 were considered early harvests.

\section{Results and Discussion}

Rainfall during the two seasons was relatively high and averaged $57 \mathrm{~cm}$ from planting through June. Pepper growth and production during the two seasons were excellent. Yield responses to row arrangement, plant spacing, and $\mathrm{N}$ rate were similar during the 2 years, and interaction effects were not significant. Therefore, mean yield data for the 2 years are presented. Early fruit yield of U.S. no. 1, U.S. no. 2, and total early marketable yield per plant and per ha were greater in year 2 than in year 1 (Tables 1 and 2). Yield differences were probably a function of differences in the times of early harvest during the two seasons. Early yields per plant were highest with one plant row/1.22-m bed and lowest with two plant rows/1.22-m bed (Table 1). Early yield per ha, however, was lowest with one row/1.22-m bed and highest with two plant rows/ $1.22-\mathrm{m}$ bed and three plant rows/1.83-m bed (Table 2).

Early fruit yields per plant were significantly higher with a 0.31 - than 0.23 -m in-row spacing (Table 1). Yields per ha were similar with the two spacings, as the $25 \%$ to $30 \%$ lower yield per plant with the closer spacing was compensated with $33.3 \%$ more plants per ha (Table 2.)

The $\mathrm{N}$ rates of 135 and $224 \mathrm{~kg} \cdot \mathrm{ha}^{-1}$ had no effect on early yield per plant or yield per ha (data not shown). Since these sites were recently cleared, the soil probably provided substantial N (Locascio

Table 1. Main effects of season, bed arrangement, and in-row spacing on early marketable fruit yield per plant.

\begin{tabular}{|c|c|c|c|c|c|c|}
\hline \multirow[b]{3}{*}{ Treatment } & \multicolumn{6}{|c|}{ Early marketable fruit yield/plant } \\
\hline & \multicolumn{2}{|c|}{ U.S. no. 1} & \multicolumn{2}{|c|}{ U.S. no. 2} & \multicolumn{2}{|c|}{ Total } \\
\hline & No. & $\mathrm{kg}$ & No. & $\mathrm{kg}$ & No. & $\mathrm{kg}$ \\
\hline \multicolumn{7}{|l|}{ Year } \\
\hline 1 & 0.9 & 0.13 & 0.13 & 0.02 & 1.0 & 0.15 \\
\hline \multirow[t]{2}{*}{2} & 1.4 & 0.22 & 0.40 & 0.06 & 1.8 & 0.28 \\
\hline & $* *$ & $* *$ & $*$ & $* *$ & $* *$ & $* *$ \\
\hline \multicolumn{7}{|c|}{ No. of rows-bed width } \\
\hline $1-1.22 \mathrm{~m}$ & 1.2 & $0.21 \mathrm{a}^{\mathrm{z}}$ & 0.32 & 0.04 & $1.6 \mathrm{a}$ & $0.25 \mathrm{a}$ \\
\hline $2-1.22 \mathrm{~m}$ & 1.0 & $0.16 \mathrm{~b}$ & 0.22 & 0.03 & $1.2 \mathrm{~b}$ & $0.19 \mathrm{~b}$ \\
\hline $2-1.83 \mathrm{~m}$ & 1.2 & $0.18 \mathrm{ab}$ & 0.29 & 0.04 & $1.5 \mathrm{ab}$ & $0.22 \mathrm{ab}$ \\
\hline \multirow[t]{2}{*}{$3-1.83 \mathrm{~m}$} & 1.1 & $0.17 \mathrm{ab}$ & 0.28 & 0.03 & $1.4 \mathrm{ab}$ & $0.20 \mathrm{ab}$ \\
\hline & NS & & NS & NS & & \\
\hline \multicolumn{7}{|c|}{ In-row spacing (m) } \\
\hline 0.23 & 1.0 & 0.16 & 0.24 & 0.03 & 1.2 & 0.19 \\
\hline \multirow[t]{2}{*}{0.31} & 1.3 & 0.20 & 0.32 & 0.04 & 1.6 & 0.24 \\
\hline & $* *$ & $* *$ & $*$ & NS & $* *$ & $* *$ \\
\hline
\end{tabular}

${ }^{\mathrm{z}}$ Mean separation by Duncan's multiple range test, $P=0.05$.

ns, ${ }^{* * *}$ Nonsignificant or significant at $P=0.05$ or 0.01 , respectively.

Table 2. Main effects of year, bed arrangement, and in-row spacing on early marketable yield.

\begin{tabular}{lccc}
\hline \hline & \multicolumn{3}{c}{ Early fruit marketable yield $\left(\mathrm{t} \cdot \mathrm{ha}^{-1}\right)$} \\
\cline { 2 - 4 } Treatment & U.S. no. 1 & U.S. no. 2 & Total \\
\hline Year & 6.3 & 0.6 & 6.9 \\
1 & 10.6 & 2.9 & 13.5 \\
2 & $* *$ & $* *$ & $* *$ \\
& & & \\
No. of rows-bed width & $6.3 \mathrm{c}^{\mathrm{z}}$ & $1.4 \mathrm{~b}$ & $7.6 \mathrm{c}$ \\
$1-1.22 \mathrm{~m}$ & $9.5 \mathrm{ab}$ & $1.9 \mathrm{ab}$ & $11.4 \mathrm{ab}$ \\
$2-1.22 \mathrm{~m}$ & $7.6 \mathrm{bc}$ & $1.6 \mathrm{ab}$ & $9.2 \mathrm{bc}$ \\
$2-1.83 \mathrm{~m}$ & $10.4 \mathrm{a}$ & $2.2 \mathrm{a}$ & $12.6 \mathrm{a}$ \\
$3-1.83 \mathrm{~m}$ & & & \\
In-row spacing (m) & 8.8 & 1.7 & 10.5 \\
0.23 & 8.2 & 1.8 & 9.9 \\
0.31 & $\mathrm{NS}$ & $\mathrm{NS}$ & $\mathrm{NS}$ \\
& &
\end{tabular}

${ }^{\mathrm{z}}$ Mean separation by Duncan's multiple range test, $P=0.05$.

Ns, ${ }^{* *}$ Nonsignificant or significant at $P=0.01$. et al., 1985) and, even though plants grown with the higher $\mathrm{N}$ rate appeared greener, the expected response to $\mathrm{N}$ rates was not obtained.

Total marketable fruit weights per plant were similar in both years (Table 3 ). Total number and weight of fruit per plant were highest with one plant row/1.22-m bed, lowest with two plant rows $/ 1.22-\mathrm{m}$ bed and three plant rows $/ 1.83-\mathrm{m}$ bed, and intermediate with two plant rows $/ 1.83-\mathrm{m}$ bed. In-row plant spacing also significantly influenced total yields per plant. Fruit number and weight per plant were $30 \%$ higher with a 0.31 - than 0.23 - $m$ in-row plant spacing. Yields per plant were not influenced by $\mathrm{N}$ rate (data not shown).

The number and weight of fruit produced were the highest with two plant rows/1.22-m bed and three plant rows/1.83-m bed, lowest with one plant row/1.22-m bed, and intermediate with two plant rows/1.83-m bed (Table 4). In-row spacings of 0.23 and 0.31 $\mathrm{m}$ and $\mathrm{N}$ rate of 135 and $224 \mathrm{~kg} \cdot \mathrm{ha}^{-1}$ had no effect on total marketable yield (data not shown).

The number of plant rows per bed and bed width influenced total yields more than in-row spacings. Plant populations were 
Table 3. Main effects of year, bed arrangement, and in-row spacing on total marketable yield per plant.

\begin{tabular}{|c|c|c|c|c|c|c|}
\hline \multirow[b]{3}{*}{ Treatment } & \multicolumn{6}{|c|}{ Total fruit marketable yield/plant } \\
\hline & \multicolumn{2}{|c|}{ U.S. no. 1} & \multicolumn{2}{|c|}{ U.S. no. 2} & \multicolumn{2}{|c|}{ Total } \\
\hline & No. & $\mathrm{kg}$ & No. & $\mathrm{kg}$ & No. & $\mathrm{kg}$ \\
\hline \multicolumn{7}{|l|}{ Year } \\
\hline 1 & 5.2 & 0.69 & 2.1 & 0.19 & 7.3 & 0.88 \\
\hline \multirow[t]{2}{*}{2} & 4.1 & 0.64 & 2.1 & 0.21 & 6.2 & 0.86 \\
\hline & $* *$ & NS & NS & $*$ & ** & NS \\
\hline \multicolumn{7}{|c|}{ No. of rows-bed width } \\
\hline $1-1.22 \mathrm{~m}$ & $5.7 \mathrm{a}^{\mathrm{z}}$ & $0.85 \mathrm{a}$ & $2.5 \mathrm{a}$ & $0.23 \mathrm{a}$ & $8.2 \mathrm{a}$ & $1.08 \mathrm{a}$ \\
\hline $2-1.22 \mathrm{~m}$ & $4.1 \mathrm{c}$ & $0.57 \mathrm{c}$ & $1.9 \mathrm{bc}$ & $0.18 \mathrm{~b}$ & $6.0 \mathrm{c}$ & $0.75 \mathrm{c}$ \\
\hline $2-1.83 \mathrm{~m}$ & $5.1 \mathrm{~b}$ & $0.73 \mathrm{~b}$ & $2.3 \mathrm{ab}$ & $0.22 \mathrm{a}$ & $7.4 \mathrm{~b}$ & $0.94 \mathrm{~b}$ \\
\hline $3-1.83 \mathrm{~m}$ & $3.7 \mathrm{c}$ & $0.52 \mathrm{c}$ & $1.8 \mathrm{c}$ & $0.18 \mathrm{~b}$ & $5.5 \mathrm{e}$ & $0.70 \mathrm{c}$ \\
\hline \multicolumn{7}{|c|}{ In-row spacing $(\mathrm{m})$} \\
\hline 0.23 & 4.1 & 0.59 & 1.8 & 0.17 & 5.9 & 0.77 \\
\hline \multirow[t]{2}{*}{0.31} & 5.2 & 0.74 & 2.4 & 0.23 & 7.6 & 0.97 \\
\hline & $* *$ & $* *$ & $* *$ & $* *$ & $* *$ & $* *$ \\
\hline
\end{tabular}

${ }^{2}$ Mean separation by Duncan's multiple range test, $P=0.05$.

Ns, ${ }^{*}{ }^{* *}$ Nonsignificant or significant at $P=0.05$ or 0.01 , respectively.

Table 4. Main effects of year and bed arrangement on total marketable yield.

\begin{tabular}{lccc}
\hline & \multicolumn{3}{c}{ Total fruit marketable yields $\left(\mathrm{t} \cdot \mathrm{ha}^{-1}\right)$} \\
\cline { 2 - 4 } Treatment & U.S. no. 1 & U.S. no. 2 & Total \\
\hline Year & 32.3 & 8.7 & 41.0 \\
1 & 29.5 & 10.2 & 39.7 \\
2 & $*$ & $*$ & $\mathrm{NS}$ \\
& & & \\
No. of rows-bed width & $26.1 \mathrm{c}^{\mathrm{z}}$ & $7.0 \mathrm{c}$ & $33.1 \mathrm{c}$ \\
$1-1.22 \mathrm{~m}$ & $35.2 \mathrm{a}$ & $10.9 \mathrm{a}$ & $46.2 \mathrm{a}$ \\
$2-1.22 \mathrm{~m}$ & $29.8 \mathrm{~b}$ & $8.9 \mathrm{~b}$ & $38.8 \mathrm{~b}$ \\
$2-1.83 \mathrm{~m}$ & $32.5 \mathrm{ab}$ & $10.8 \mathrm{a}$ & $43.3 \mathrm{a}$ \\
$3-1.83 \mathrm{~m}$ & & &
\end{tabular}

yMean separation by Duncan's multiple range test, $P=0.05$.

Ns, ${ }^{*}$ Nonsignificant or significant at $P=0.05$.

twice as high with two plant rows/1.22-m bed and three plant rows/ $1.83-\mathrm{m}$ bed (53,750 plants/ha with $0.31-\mathrm{m}$ in-row spacing) as with one plant row/1.22-m bed (26,875 plants/ha with $0.31-\mathrm{m}$ in-row spacing). Yields per plant were $50 \%$ greater with the lower population but, with the $2 \mathrm{x}$ plant population, the yields per ha were significantly greater with the two former than the latter row-bed arrangement. Fruit yields per plant were also greater with the wider spaced $0.31-\mathrm{m}$ in-row spacing than with the $0.23-\mathrm{m}$ spacing. Differences in yield were $30 \%$, thus, with only $33.3 \%$ difference in population, yield per ha was similar with the two in-row plant spacings.

Plant populations were identical with two plant rows/1.22-m bed and with three plant rows $/ 1.83-\mathrm{m}$ bed with the same in-row spacing. But, yields per plant were $5 \%$ to $10 \%$ greater (nonsignificant) with two plant rows/1.22-m bed than three rows $/ 1.83-\mathrm{m}$ bed (Table 3). Small but nonsignificant pepper yield differences due to plant arrangement with similar plant population were reported by Batal and Smittle (1981). Two plant rows/1.22-m bed probably allowed better light use than three plant rows/1.83-m bed. This assumption was supported by the significantly lower yield per plant with rows located in the middle than those on the side of the $1.83-\mathrm{m}$ beds (Table 5). Although the overall effect of $\mathrm{N}$ rate with all row arrangements on yield was nonsignificant, plants growing in three rows $/ 1.83-\mathrm{m}$ bed responded to $\mathrm{N}$ rate. The yield per plant of U.S. no. 1 fruit was significantly higher with 224 than $135 \mathrm{~kg} \mathrm{~N} /$ ha. In contrast, the yield per plant of U.S. no. 2 fruit was lower with the high $\mathrm{N}$ rate, and the total yield per plant was not influenced by $\mathrm{N}$ rate.

Leaf tissue $\mathrm{N}$ concentrations of plants grown with three plant rows $1.83-\mathrm{m}$ bed were lower than with the other arrangement early and midseason (Table 6). At the last sampling, row arrangement effects were small. In-row plant spacings of 0.23 and $0.31 \mathrm{~m}$ had no effect of leaf tissue $\mathrm{N}$ concentrations. Leaf $\mathrm{N}$ concentrations were consistently influenced by $\mathrm{N}$ rate throughout the season. Leaf tissue $\mathrm{N}$ concentrations were significantly higher with 224 than

Table 5. The effects of row location on the 1.83-m bed and $\mathrm{N}$ rate on marketable yield per plant. Mean of two seasons.

\begin{tabular}{|c|c|c|c|c|c|c|}
\hline \multirow[b]{3}{*}{ Treatment } & \multicolumn{6}{|c|}{ Total marketable fruit yield/ plant } \\
\hline & \multicolumn{2}{|c|}{ U.S. no. 1} & \multicolumn{2}{|c|}{ U.S. no. 2} & \multicolumn{2}{|c|}{ Total } \\
\hline & No. & $\mathrm{kg}$ & No. & $\mathrm{kg}$ & No. & $\mathrm{kg}$ \\
\hline \multicolumn{7}{|l|}{ Row location } \\
\hline Middle row & 3.2 & 0.46 & 1.5 & 0.15 & 4.7 & 0.61 \\
\hline \multirow[t]{2}{*}{ Outside row } & 4.6 & 0.56 & 2.0 & 0.19 & 6.0 & 0.75 \\
\hline & $* *$ & $* *$ & $* *$ & $* *$ & $* *$ & $* *$ \\
\hline \multicolumn{7}{|l|}{$\mathrm{N}\left(\mathrm{kg} \cdot \mathrm{ha}^{-1}\right)$} \\
\hline 135 & 3.4 & 0.48 & 1.9 & 0.18 & 5.3 & 0.66 \\
\hline \multirow[t]{2}{*}{224} & 3.7 & 0.54 & 1.6 & 0.16 & 5.3 & 0.70 \\
\hline & NS & $*$ & $*$ & $*$ & NS & NS \\
\hline
\end{tabular}

$\overline{\mathrm{NS},{ }^{*}, * *}$ Nonsignificant or significant at at $P=0.05$ or 0.01 , respectively. 
Table 6. Main effects of year, row arrangement, in-row plant spacing, and $\mathrm{N}$ rate on leaf tissue $\mathrm{N}$ concentrations.

\begin{tabular}{lccc}
\hline \hline & \multicolumn{3}{c}{ Leaf N concn $\left(\mathrm{g} \cdot \mathrm{kg}^{-1}\right)$} \\
\cline { 2 - 4 } Treatment & Early & Middle & Late \\
\hline Year & 52.3 & 40.9 & 32.8 \\
1 & 57.1 & 44.0 & 35.3 \\
2 & $* *$ & $* *$ & $* *$ \\
& & & \\
No. of rows-bed width & $56.9 \mathrm{a}^{\mathrm{z}}$ & $45.7 \mathrm{a}$ & $35.2 \mathrm{a}$ \\
$1-1.2 \mathrm{~m}$ & $54.5 \mathrm{a}$ & $41.5 \mathrm{bc}$ & $32.9 \mathrm{~b}$ \\
$2-1.2 \mathrm{~m}$ & $56.3 \mathrm{a}$ & $43.0 \mathrm{~b}$ & $34.2 \mathrm{ab}$ \\
$2-1.8 \mathrm{~m}$ & $51.0 \mathrm{~b}$ & $39.5 \mathrm{c}$ & $34.0 \mathrm{ab}$ \\
$3-1.8 \mathrm{~m}$ & & & \\
In-row spacing (m) & 54.3 & 42.4 & 33.8 \\
0.23 & 55.0 & 42.5 & 34.3 \\
0.31 & $\mathrm{NS}$ & $\mathrm{NS}$ & $\mathrm{NS}$ \\
& & & \\
$\mathrm{N}\left(\mathrm{kg} \cdot \mathrm{ha}^{-1}\right)$ & 52.5 & 39.6 & 32.1 \\
135 & 56.8 & 45.2 & 36.0 \\
224 & $* *$ & $* *$ & $* *$ \\
& & &
\end{tabular}

${ }^{\mathrm{z}}$ Mean separation by Duncan's multiple range test, $P=0.05$.

Ns, ${ }^{* *}$ Nonsignificant or significant at $P=0.01$, respectively.

$135 \mathrm{~kg} \cdot \mathrm{ha}^{-1}$ at all samplings. Leaf tissue $\mathrm{N}$ concentration were $>50$ $\mathrm{g} \cdot \mathrm{kg}^{-1}$ early in the season and $>30 \mathrm{~g} \cdot \mathrm{kg}^{-1}$ at the end of the season and were considered adequate with all treatments (Hochmuth and Hanlon, 1989).

In past studies on adjacent soils, pepper responded with increased yields to an $\mathrm{N}$ rate of $224 \mathrm{~kg} \cdot \mathrm{ha}^{-1}$ (Locascio et al., 1981). In the present study, both soil sites had not been previously cropped. The soil areas were limed and soil organic matter content and nitrification were probably higher than in areas previously cultivated. Apparently, $135 \mathrm{~kg} \mathrm{~N} / \mathrm{ha}$ was adequate to prevent $\mathrm{N}$ from limiting yield except with the highest population with three plant rows/1.83-m bed.

Yield per plant was inversely related to plant population. With $30 \%$ higher yield with an in-row spacing of 0.31 than $0.23 \mathrm{~m}$, the $33.3 \%$ increase in plant population with the $0.23-\mathrm{m}$ spacing compensated for the fewer plants and, as a result, yields were similar with the two in-row spacings. Yields per plant were also
$30 \%$ higher with the row arrangement that had the fewest plants per ha (one plant row/1.22-m bed) than with the most plants (two plant rows/1.22-m bed and three plant rows/1.83-m bed). With the difference in plant population of $100 \%$, total yields were significantly higher ( $25 \%$ to $35 \%$ ) with the latter row arrangements than with the most commonly used one plant row/1.22-m bed or two plant rows/1.83-m bed.

\section{Literature Cited}

Batal, K.M. and D.A. Smittle. 1981. Response of bell pepper to irrigation, nitrogen, and plant population. J. Amer. Soc. Hort. Sci. 106:259-262.

Brinen, G.H., S.J. Locascio, and G.W. Elmstrom. 1979. Plant and row spacing, mulch, and fertilizer rate effects on watermelon production. J. Amer. Soc. Hort. Sci. 104:724-726.

Bryan, H.H., J.W. Strobel, and J.D. Dalton. 1968. Effects of plant populations, fertilizer rates on tomato yield on Rockdale soil. Proc. Fla. State Hort. Soc. 80:149-155.

Everett, P.H. and R. Subramanya. 1983. Pepper production as influenced by plant spacing and nitrogen-potassium rates. Proc. Fla. State Hort. Soc. 96:79-82.

Florida Agricultural Statistical Service. 1993. Florida Agricultural Statistical Service vegetable summary. 1991-1992. Fla. Agr. Stat. Serv., Orlando.

Hochmuth, G.J. and E.A. Hanlon. 1989. Fertilizer management for bell pepper production in Florida. Fla. Agr. Ext. Serv., Gainesville. Circ. S357.

Hochmuth, G.J., D.N. Maynard, and M. Sherman. 1988. Pepper production guide for Florida. Fla. Agr. Ext. Serv., Gainesville. Circ. 102E.

Kirk, P.L. 1950. Kjeldahl method for total nitrogen. Anal. Chem. 22:354358.

Locascio, S.J., J.G.A. Fiskell, D.A. Graetz, and R.D. Hauck. 1985. Nitrogen accumulation by pepper as influenced by mulch time of fertilizer application. J. Amer. Soc. Hort. Sci. 110:325-328.

Locascio, S.J., J.G.A. Fiskell, and F.G. Martin. 1981. Responses of bell pepper to nitrogen sources. J. Amer. Soc. Hort. Sci. 106:628-632.

Locascio, S.J. and W.M. Stall. 1982. Plant arrangement for increased bell pepper yield. Proc. Fla. State Hort. Soc. 95:333-335.

Navarro, A.A. and S.J. Locascio. 1971. Influence of population density, row arrangement and fertilizer rate on the single-harvest yield of fresh market tomatoes. Proc. Fla. State Hort. Soc. 84:129-131.

Sayre, C.B. 1959. Spacing of cannery tomatoes. Proc. Amer. Soc. Hort. Sci. 73:305-311.

Stoffella, P.J. and H.H. Bryan. 1988. Plant population influences growth and yields of bell pepper. J. Amer. Soc. Hort. Sci. 113:835-839. 